\title{
Prevalence of Diabetes Mellitus in a Rural, Agrarian Community in South-South Nigeria
}

\author{
*Oghenekaro Godwin Egbi', Sulaiman Dazumi Ahmed ${ }^{2}$
}

\begin{abstract}
Background: Diabetes mellitus (DM) is a global public health threat, often associated with other co-morbidities with significant morbidities and mortality. The aim of this study was to determine the prevalence of DM in a rural agrarian community in Nigeria.
\end{abstract}

Methodology: This cross-sectional study, using quantitative methods, was carried out in Ayua community in Etsako West local government area of Edo state, South-South Nigeria. Structured questionnaire was intervieweradministered while socio-demographics, anthropometric data, blood pressure and weight measurements as well as random blood glucose were obtained from participants.

Findings: Two hundred and sixteen participants (58 males, 158 females) completed the study with a mean age of $54.2 \pm 16.4$ years. Diabetes was found in $30(13.9 \%)$ participants and undiagnosed in $40.0 \%$ while hypertension and obesity were found in $61(28.2 \%)$ and $57(26.4 \%)$ respectively. Diabetes was independently predicted by age $>50$ years $(\mathrm{OR}=5.7)$ and the presence of a family history of $\mathrm{DM}(\mathrm{OR}=43.0)$ with $\mathrm{p}<0.001$ each $)$ but not by obesity $(\mathrm{p}=0.860)$, hypertension $(\mathrm{p}=0.477)$ or family history of hypertension $(\mathrm{p}=0.09)$.

Conclusion: Considering the high prevalence of DM and co-morbidities in this rural agrarian community, we recommend regular screening of adults for these conditions.

Keywords: Diabetes mellitus, Hypertension, Nigeria, Rural

\author{
*Corresponding Author \\ Oghenekaro Godwin Egbi \\ http://orcid.org/0000-0001-9417-3452 \\ E-mail: drkoge@yahoo.com
}

${ }^{1}$ Department of Internal Medicine, Niger Delta University Teaching Hospital, Okolobiri, Bayelsa State.

${ }^{2}$ Department of Internal Medicine, Irrua Specialist Teaching Hospital, Irrua, Edo State.

Received: May 20, 2020

Accepted: May 24, 2020

Published: September 30, 2020

Research Journal of Health Sciences subscribed to terms and conditions of Open Access publication. Articles are distributed under the terms of Creative Commons Licence (CC BY-NC-ND 4.0). (http://creativecommons.org/licences/by-nc-nd/4.0).

https://dx.doi.org/10.4314/rejhs.v8i3.6 


\title{
Prévalence du diabète sucré dans une communauté rurale et agraire du Sud-Sud du Nigéria
}

\author{
*Oghenekaro Godwin Egbi ${ }^{1}$, Sulaiman Dazumi Ahmed ${ }^{2}$
}

\section{Résumé}

Contexte général de l'étude : Le diabète sucré (DS) est une menace pour la santé publique mondiale, souvent associée à d'autres comorbidités avec des morbidités et une mortalité importantes. Le but de cette étude était de déterminer la prévalence de la DS dans une communauté agraire rurale au Nigéria.

Méthode de l'étude : Cette étude transversale utilisant des méthodes quantitatives, a été réalisée dans la communauté d'Ayua dans la Zone Gouvernementale Etsako Ouest de l'État d'Edo, au Sud-Sud du Nigéria. Le questionnaire structuré a été administré par l'intervieweur tandis que les données sociodémographiques, les données anthropométriques, la tension artérielle et le poids ainsi que la glycémie aléatoire ont été obtenues des participants.

Résultats de l'étude : Deux cent seize participants ( 58 hommes, 158 femmes) ont terminé l'étude avec un âge moyen de 54,2 $\pm 16,4$ ans. Le diabète a été trouvé chez $30(13,9 \%)$ participants et non diagnostiqué chez 40,0\%, tandis que l'hypertension et l'obésité ont été retrouvées respectivement chez $61(28,2 \%)$ et $57(26,4 \%)$. Le diabète a été prédit indépendamment par l'âge $>50$ ans $(\mathrm{OR}=5,7)$ et la présence d'antécédents familiaux de $\mathrm{DM}(\mathrm{OR}=$ 43,0; $<<0,001$ chacun) mais pas par l'obésité $(p=0,860)$, l'hypertension $(p=0,477)$ ou antécédents familiaux d'hypertension $(\mathrm{p}=0,09)$.

Conclusion : Compte tenu de la forte prévalence du diabète et des comorbidités dans cette communauté agraire rurale, nous recommandons un dépistage régulier des adultes pour ces conditions.

Mots-clés: Diabète sucré, hypertension, Nigéria, rural

\author{
*Corresponding Author \\ Oghenekaro Godwin Egbi \\ http://orcid.org/0000-0001-9417-3452 \\ E-mail: drkoge@yahoo.com
}

${ }^{1}$ Department of Internal Medicine, Niger Delta University Teaching Hospital, Okolobiri, Bayelsa State.

${ }^{2}$ Department of Internal Medicine, Irrua Specialist Teaching Hospital, Irrua, Edo State. 


\section{INTRODUCTION}

Diabetes mellitus (DM) characterized by hyperglycemia, is a global health concern and has been considered one of the most challenging health problems of the $21^{\text {st }}$ century (1). The seriousness of the disease is due to the associated morbidities and mortality. DM was responsible for 1.6 million deaths globally in 2016 with associated increase in premature mortality over the years (2). DM could be complicated with other morbidities such as renal failure, stroke, heart and cardiovascular disease. It is also a leading cause of blindness and amputation of the lower limbs (2). DM commonly exists with comorbid conditions such as hypertension, obesity and dyslipidemia, which together constitute the metabolic syndrome.

Recently, there has been a relative rapid rise in the prevalence of DM in low- and middle- income countries compared with high - income countries (2). In Nigeria, its prevalence is believed to have been on the increase $m$ the past six decades (3). Nigeria is reported as having the highest burden in Africa (4). The last national survey conducted almost three decades ago reported a prevalence of $2.2 \%$ among Nigerians (5). However, a recent systematic review and meta-analysis reported rates that ranged between $3.3 \%$ to $10 \%(6)$. A comparison of prevalence studies in urban and rural areas seem to suggest generally lower rates in the latter $(3,7)$. Physical activities associated with farming which is common among rural dwellers have been shown to offer some protection against $\mathrm{DM}(8,9)$. We therefore hypothesize that the prevalence of DM in an agrarian community would be relatively low. The aim of this study was to determine the prevalence of diabetes among adults in Ayua, a rural agrarian community, in Edo State, Nigeria. To the best of the authors' knowledge, no such study had been carried out in this community or neighboring ones.

\section{MATERIALS AND METHODS}

The study was conducted in Ayua community in Etsako West local government area of Edo state as part of a health outreach program targeted at rural communities in South-South Nigeria. Ayua is a small rural settlement of about three thousand individuals (10) who are predominantly farmers. It was a descriptive cross-sectional study of adults who attended a health sensitization rally that included screening for diabetes and associated factors in March, 2016. All adults who were available for the exercise and who met the inclusion criteria were selected for the study. A health awareness campaign was done and participants invited to the village community hall where they were screened for diabetes and associated conditions such as obesity and hypertension after receiving a health sensitization talk. Pregnant women, lactating mothers and individuals with other known chronic medical ailments such as kidney or liver disease were excluded from the study.

Quantitative method of data collection was employed through the use of an intervieweradministered structured questionnaire. The questionnaire was used to collect important information from participants such as age, sex, medical history, anthropometric data, blood pressure and blood glucose readings. Relevant medical history obtained included a previous or family history of hypertension as well as a previous or family history of DM. Anthropometry done included measurements of weight, height and body mass index (BMI). Weight was measured using a bathroom scale with the feet of the participants on the centre of the flat surface after participants had removed all heavy outer garments and shoes and approximated to the nearest $0.5 \mathrm{~kg}$. Similarly, measurement of height was done to the nearest $0.5 \mathrm{~cm}$ with a standiometer according to standard procedure. Participants on wheel chair or those who could not stand were excluded from anthropometric measurements. Measurement bias was eliminated as a single trained staff took all measurements during same time interval. BMI was calculated by dividing the weight $(\mathrm{kg})$ by the square of the height $\left(\mathrm{m}^{2}\right)$.

Blood pressure measurements was taken with participants seated for at least 5 minutes and not having taken alcohol, tobacco or any drug that could affect blood pressure at least an hour before measurement. An average of two recordings was taken a minute apart to the nearest $2 \mathrm{mmHg}$.

\section{Operational Definitions}

Diabetes was defined as elevated random plasma glucose $>11.1 \mathrm{mmol} / 1$ or the presence of a previous history based on self-report of having been diagnosed diabetic by a physician (11). For the purpose of the study, participants were classified as being undiagnosed if they met the above biochemical criterion for DM in the absence of a previous diagnosis. Participants were said to have a family history of DM if a first degree relative had been diagnosed with it. 
Hypertension was defined according to the Joint National Committee on Prevention, Detection. Evaluation and Treatment of high blood pressure (JNC) 7 criteria as average blood pressure of $>140 / 90$ $\mathrm{mm} \mathrm{Hg}$ after two readings (12) or a previous history based on self-report while those with a history of diagnosis of hypertension in a first degree relative were considered as having a family history of hypertension.

Obesity was defined as BMI $>30 \mathrm{~kg} / \mathrm{m}^{2}$ while lesser values were described as 'non-obese.'

\section{Ethical Consideration}

This was a health outreach program with obvious benefits to the participants and community as a whole. Subjects found to be diabetic or hypertensive during the course of the exercise were referred for follow-up in a nearby hospital while those found to be obese were counseled.

Ethical clearance for the multi-centre health survey, of which this study was a part, was obtained from the Ethical and Research Committee of the Bayelsa State Ministry of Health. The purpose of this study and details of the tests were explained to all participants who were also told that participation was voluntary. All who agreed to the terms were required to give an informed consent. The risk to the subjects were observed to be minimal. Permission was given by the chairman of the local government council as well as the paramount ruler of the community.

\section{Data Analysis}

Data was saved, stored and analyzed using IBM SPSS version 20.0. Continuous variables were analyzed using measures of dispersion such as mean, range and standard deviation. Categorical variables such as the presence of diabetes and other associated conditions were explored using frequency tables, cross-tabulation and chi-square (or Fisher's exact as applicable). The strength of associations was tested with binary logistic regression. All statistical analyses were 2-tailed and set at the 5\% level of significance.

\section{RESULTS}

Although 219 participants commenced the study, $216(98.6 \%)$ completed it with available data for analysis. The mean age of participants who completed the survey was $54.18 \pm 16.38$ years with a range of 18-90 years. Majority 158(73.1\%) of them were females.

Table 1: Demographic and clinical profile of participants

\begin{tabular}{|c|c|c|c|c|}
\hline Variable & All (\%) & Male (\%) & Female (\%) & $P$ \\
\hline \multicolumn{5}{|l|}{ Age (yrs) } \\
\hline$<50$ & $90(41.7)$ & $21(36.2)$ & $69(43.7)$ & \multirow[t]{3}{*}{0.20} \\
\hline$>50$ & $126(58.3)$ & $37(63.8)$ & $89(56.3)$ & \\
\hline Total & $216(100.0)$ & $58(100.0)$ & $89(100.0)$ & \\
\hline \multicolumn{5}{|l|}{ BMI } \\
\hline Obese & $57(26.4)$ & $8(13.8)$ & $49(31.0)$ & \multirow[t]{3}{*}{$.02 *$} \\
\hline Not obese & $159(73.6)$ & $50(86.2)$ & $109(69.0)$ & \\
\hline Total & $216(100.0)$ & $58(100.0)$ & $158(100.0)$ & \\
\hline \multicolumn{5}{|c|}{ Previous History of HTN } \\
\hline Yes & $23(10.6)$ & $3(5.2)$ & $20(12.7)$ & \multirow[t]{3}{*}{0.09} \\
\hline No & 193(89.4) & $55(94.8)$ & $138(87.3)$ & \\
\hline Total & $216(100.0)$ & $216(100.0)$ & $216(100.0)$ & \\
\hline \multicolumn{5}{|c|}{ Previous History of DM } \\
\hline Yes & $18(8.3)$ & $1(1.7)$ & $17(10.8)$ & \multirow[t]{3}{*}{0.05} \\
\hline No & $198(91.7)$ & $57(98.3)$ & $141(89.2)$ & \\
\hline Total & $216(100.0)$ & $58(100.0)$ & $158(100.0)$ & \\
\hline \multicolumn{5}{|c|}{ Family History of HTN } \\
\hline Yes & $21(9.7)$ & $3(5.2)$ & $18(11.4)$ & \multirow[t]{3}{*}{0.21} \\
\hline No & $195(90.3)$ & $55(94.8)$ & $140(88.6)$ & \\
\hline Total & $216(100.0)$ & $58(100.0$ & $158(100.0)$ & \\
\hline \multicolumn{5}{|c|}{ Family History of DM } \\
\hline Yes & $17(7.9)$ & $1(1.7)$ & $1(1.7)$ & \multirow[t]{3}{*}{0.05} \\
\hline No & $199(92.9)$ & $57(98.3)$ & $57(98.3)$ & \\
\hline Total & $216(100.0)$ & $216(100.0)$ & $216(100.0)$ & \\
\hline
\end{tabular}

$\mathrm{BMI}=$ body mass index, $\mathrm{DM}=$ diabetes, $\mathrm{HTN}=$ hypertension, $\mathrm{yrs}=$ years 
Diabetes was found in $30(13.9 \%)$ of participants. Twenty-four (15.2\%) of the 158 females and six $(10.3 \%)$ of the 58 males had DM. The prevalence of DM did not differ between gender $(\mathrm{p}=$ $0.250)$. On the overall, thirteen persons $(6 \%)$ had elevated blood glucose. Twelve (92.3\%) of the thirteen individuals with elevated blood glucose had no prior history of DM. However, only $1(5.6 \%)$ of the patient with a history of DM had elevated glucose during the screening. Hypertension was found in $61(28.2 \%)$ of participants while $57(26.4 \%)$ had generalized obesity. Females had a higher frequency of generalized obesity compared with males $(\mathrm{p}=$ $0.02)$.
Factors associated with DM in univariate analysis were 'family history of DM', 'family history of hypertension' and 'presence of hypertension' (< 0.001 each). However, 'a family history of DM' and 'age of participants' were the only factors showing significant association with DM in multivariate analysis. ( $\mathrm{p}=0.03$ and 0.04$)$ respectively. Participants who were older than 50 years or who had a family history of DM had 7- and 42-times increased odds for DM respectively.

There was however no association between the presence of DM and sex $(\mathrm{p}=0.811)$, presence of hypertension $(\mathrm{p}=0.477)$ or family history of hypertension (0.09).

Table 2: Mean and range of clinical parameters for participants

\begin{tabular}{lllllll}
\hline & \multicolumn{2}{c}{ All } & \multicolumn{2}{c}{ Male } & \multicolumn{2}{c}{ Female } \\
\cline { 2 - 7 } Parameter & Mean (SD) & Range & Mean (SD) & Range & Mean (SD) & Range \\
\hline Age & $54.01(16.64)$ & $18-90$ & $57.33(17.92)$ & $18-90$ & $52.76(16.01)$ & $18.0-86.0$ \\
Weight $(\mathrm{kg})$ & $72.54(16.68)$ & $35-140$ & $74.59(14.81)$ & $35-106$ & $71.76(17.316)$ & $43.0-140.0$ \\
Height $(\mathrm{m})$ & $1.63(0.11)$ & $1.10-1.90$ & $1.71(0.09)$ & $1.10-1.80$ & $1.60(0.10)$ & $1.47-1.90$ \\
BMI $\left(\mathrm{kg} / \mathrm{m}^{2}\right)$ & $27.38(6.40)$ & $16.2-55.4$ & $25.29(4.45)$ & $16.2-36.7$ & $28.16(6.86)$ & $17.0-55.4$ \\
SBP $(\mathrm{mmHg})$ & $130.64(20.60)$ & $70-220$ & $133.81(17.82)$ & $100-200$ & $129.46(21.48)$ & $70-220$ \\
DBP $(\mathrm{mmHg})$ & $78.9(12.4)$ & $40-110$ & $78.97(12.68)$ & $40-110$ & $78.83(12.37)$ & $40-100$ \\
\hline
\end{tabular}

$\mathrm{SD}=$ standard deviation, $\mathrm{BMI}=$ body mass index, $\mathrm{SBP}=$ systolic blood pressure, $\mathrm{DBP}=$ diastolic blood pressure

Table 3: Factors associated with hyperglycemia in univariate analysis

\begin{tabular}{|c|c|c|c|c|}
\hline Factor & B & $\boldsymbol{P}$ & OR & CI \\
\hline \multicolumn{5}{|l|}{ Age } \\
\hline$<50$ & 0.421 & 0.32 & 1 & \\
\hline$>50$ & & & 1.51 & $0.67-3.40$ \\
\hline \multicolumn{5}{|l|}{ Sex } \\
\hline Male & 0.440 & 0.36 & 1 & \\
\hline Female & & & 1.55 & $0.60-4.01$ \\
\hline \multicolumn{5}{|l|}{ BMI } \\
\hline Not obese & -0.006 & 0.98 & 1 & \\
\hline Obese & & & 1.01 & $0.42-2.41$ \\
\hline \multicolumn{5}{|c|}{ Presence of HTN } \\
\hline No & 3.995 & $<0.001 *$ & 1 & \\
\hline Yes & & & 54.30 & $17.19-171.53$ \\
\hline \multicolumn{5}{|c|}{ Family History of HTN } \\
\hline No & 4.096 & $<0.001^{*}$ & 1 & \\
\hline $\mathrm{Y}$ & & & 59.50 & $17.48-202.74$ \\
\hline \multicolumn{5}{|c|}{ Family History of DM } \\
\hline No & 5.354 & $<0.001^{*}$ & 1 & \\
\hline Yes & & & 211.43 & $26.010-1712.90$ \\
\hline
\end{tabular}

$* *$ statistically significant, $\mathrm{OR}=$ odds ratio, $\mathrm{CI}=$ confidence interval, $\mathrm{BMI}=$ body mass index, $\mathrm{HTN}=$ hypertension, $\mathrm{DM}=$ diabetes 
Table 4: Factors associated with hyperglycemia in multivariate analysis

\begin{tabular}{|c|c|c|c|}
\hline Factor & $\boldsymbol{P}$ & OR & CI \\
\hline \multicolumn{4}{|l|}{ Age } \\
\hline$<50$ & $0.04 *$ & 1 & \\
\hline$>50$ & & 5.725 & $1.127-29.077$ \\
\hline \multicolumn{4}{|l|}{ Sex } \\
\hline Male & 0.81 & 1 & \\
\hline Female & & 0.861 & $0.254-2.922$ \\
\hline \multicolumn{4}{|l|}{ Obesity } \\
\hline No & 0.86 & 1 & \\
\hline Yes & & 0.889 & $0.242-3.269$ \\
\hline \multicolumn{4}{|c|}{ Presence of HTN } \\
\hline No & 0.48 & 1 & \\
\hline Yes & & 1.523 & $0.478-4.851$ \\
\hline \multicolumn{4}{|c|}{ Family History of HTN } \\
\hline No & 0.09 & 1 & \\
\hline Yes & & 10.097 & $0.699-145.835$ \\
\hline \multicolumn{4}{|c|}{ Family History of DM } \\
\hline No & $0.03 *$ & 1 & \\
\hline Yes & 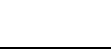 & 42.974 & $1.512-1221.816$ \\
\hline
\end{tabular}

\section{DISCUSSION}

The prevalence of diabetes in this study was high. Even more worrisome was the proportion of hyperglycemia in those without a previous diagnosis, which was as high as $6 \%$ in the population screened. This is more than the $4 \%$ recorded among elderly population in North Central Nigeria (3) and NorthWest Nigeria (13). Apart from geographic differences that could account for the difference in findings, it is also important to note that the latter study was carried out several years before ours. More recent studies in rural areas however reported higher prevalence rates, though lower than what we found. Arugu et al reported a rate of $8.0 \%$ in a rural district in Rivers State (14) higher than the $2.2 \%$ which Alikor et al had reported some years before in a similar setting in the same state (15). An earlier study done some years prior to our study in some rural communities in the same state revealed a much lower DM prevalence of $4.6 \%$ (16). From the foregoing, it is reasonable to opine that the prevalence of DM is on the rise, and that rural communities are not spared. Rural- urban disparities in prevalence of DM have been severally noted with most studies reporting a higher rate in urban communities $(13,17)$. It appears however that this rural-urban disparity is gradually becoming eroded in recent times. Reasons that may be ascribed to this may include changes in dietary patterns in rural communities, increasing prevalence of associated medical conditions such as obesity and hypertension as well as changing occupation patterns.

The study also reported high prevalence of other non-communicable diseases such as hypertension and obesity. This is not surprising as studies in rural communities in some settings have similarly shown increasing trends in prevalence of hypertension and obesity. Oladapo et al found a prevalence of $20.8 \%$ in a rural population composed mainly of farmers, artisans and traders (18) while Onwubere et al found an even higher rate of $46.4 \%$ (19). These are higher than the rates reported from studies conducted a few decades ago in urbanized settings (20). Our findings also corroborate the high prevalence of generalized obesity that has been reported from rural communities in recent times $(21,22)$. However, the prevalence of $64.49 \%$ among women reported by Adienbo et al was much higher than what we found. This high prevalence was ascribed to the 'practice of fattening' which is common among them (21). Okesina et al had reported an obesity prevalence of only $2.0 \%$ among some rural communities in North Eastern Nigeria two decades ago (23).

The independent predictors for DM in the study were older age and family history of diabetes. Age is a well-known established risk factor for DM. Older adults are at high risk for diabetes with surveillance data suggesting that a significant proportion of older 
adults may be affected (24). The American Diabetes Association ADA therefore recommends regular screening of blood glucose for all adults aged $\geq 45$ years as well as adults with risk factors for DM (25). Age and family history of DM were also found to be independently associated with DM in previous studies $(6,14)$. In this study, the presence of hypertension also showed some association with DM in univariate analysis though the association ceased to remain significant on multivariate analysis. This is similar to the findings in a Thailand study (26). However, longitudinal studies have established that the development of hypertension and diabetes predict each other over time (27). Our study did not demonstrate any significant association between DM and obesity. This comes as no surprise since we did not particularly make any distinction between type 2 $\mathrm{DM}$ and the other classes. While type $2 \mathrm{DM}$ is traditionally associated with obesity and hypertension $(27,28)$, same cannot be said of the other types of DM. However, in a study among AfroTrinidadians, no significant difference in BMI was reported between those who had type $2 \mathrm{DM}$ and those who did not (29).

In conclusion, the prevalence of DM and comorbid medical conditions such as hypertension and obesity in this rural community was high. Diabetes was predicted by older age and a positive family history of DM. The high prevalence of these noncommunicable diseases suggests that the phenomenon of epidemiologic transition is not restricted to urban communities in Nigeria. There is a need for targeted screening of persons living in rural communities for diabetes and its associated risk factors especially among older individuals.

The study had some limitations. Blood glucose and blood pressure measurements were done on only one occasion instead of a minimum of two occasions. Also, random plasma glucose measurement was used in the study, which falls short of the ideal fasting plasma glucose or 2-h plasma glucose. Use of selfreport in diagnosis may be subject to bias. Central obesity and other traditional risk factors for DM such as dietary intake, alcohol consumption, smoking, physical inactivity as well as investigations such as lipid profile were not assessed. Considering the cross-sectional design of this study, a causal relationship cannot be established among the variables tested. Lastly, the non-probability sampling technique used could have introduced some selection bias.

\section{CONFLICT OF INTEREST}

We declare that there is no potential conflict of interest.

\section{REFERENCES}

1. Zimmet PZ, Magliano DJ, Herman WH, Shaw JE. Diabetes: a 21 st century challenge. Lancet Diabetes Endocrinol 2014;2(1):56-64

2. World Health Organization. Diabetes. http://www.who.int.. Updated 8 June 2020. Accessed 30 July 2020.

3. Chuhwak EK, Okeahialam BN, Ogbonna C, Pam SD. Diabetes in elderly Nigerians: A survey of a rural area in north-central Nigeria. J Med Trop 2019;21:51-5.

4. Ekpebegh C. Diabetes mellitus in Nigeria: the past, present and future. World J Diabetes 2014; 5:905-11.

5. Akinkugbe OO. Non-communicable diseases in Nigeria-final report of a national survey. Lagos: Federal Ministry of Health-National Expert Committee on Non-Communicable Diseases; 1997.p. 65-8.

6. Uloko AE, Musa BM, Ramalan MA, Gezawa ID, Puepet FH, Uloko AT et al. Prevalence and Risk Factors for Diabetes Mellitus in Nigeria: A Systematic Review and Meta-Analysis. Diabetes Ther 2018;9(3): 1307-1316.

7. Ohwovoriole AE, Kuti JA, Kabiawu SI. Casual blood glucose levels and prevalence of undiscovered diabetes mellitus in Lagos metropolis Nigerians. Diabetes Res Clin Pract 1998; 4:153-8.

8. Dyck R, Karunanayake C, Pahwa P, Hagel L, Lawson J, Rennie D et al. Prevalence, risk factors and co-morbidities of diabetes among adults in rural Saskatchewan: the influence of farm residence and agriculture-related exposures. BMC Public Health. 2013; 13: 7.

9. Qi L, Hu FB, Hu G. Genes, environment, and interactions in prevention of type 2 diabetes: a focus on physical activity and lifestyle changes. Curr Mol Med. 2008; 8:519-532. 5.

10. National Population Commission of Nigeria [N Pop C]. Population and Housing Census Facts and Figures; 2006.

11. American Diabetes Association. Diabetes Care 2010; 33(Suppl 1): S62-S69. 
12. Chobanian AV, Bakris GL, Black HR, Cushman WC, Green LA, Izzo JL et al. The seventh report of the Joint National Committee on Prevention, Detection, Evaluation, and Treatment of high blood pressure: the JNC 7 report. JAMA.2003; 289(19):2560-72.

13. Sabir AA, Balarabe $S$, Sani AA, Isezuo SA, Bello KS, Jimoh AO et al Prevalence of diabetes mellitus and risk factors among the suburban population of North Western Nigeria. Sahel Med J 2017; 20(4): 168-172.

14. Arugu GM, Maduka O. Risk factors for diabetes mellitus among adult residents of a rural District in Southern Nigeria: Implications for prevention and control. Niger J Clin Pract 2017; 20(12): 1544-1549.

15. Alikor CA, Emem-Chioma PC. Epidemiology of diabetes and impaired fasting glucose in a rural community of Nigerian Niger Delta region. Niger J Med 2015; 24 (2):114-124.

16. Isara AR, Okundia PO. The burden of hypertension and diabetes mellitus in rural communities in southern Nigeria. Pan Afr Med J. 2015;20: 103.

17. Toth G, Szabo D, Sandor GL. Rural-urban disparities in the prevalence of diabetes and diabetic eye complications in Hungary. Spektrum Augenheilkd 2019. https://doi.org/ 10.1007/s00717-019-00433-6.

18. Oladapo OO, Falase AO, Salako L, Sodiq O, Shoyinka K, Adedapo K. A prevalence of cardiometabolic risk factors among a rural Yoruba south-western Nigerian population: a population-based survey. Cardiovasc J Afr 2010; 21 (1): 26-31.

19. Onwubere BJC, Ejim EC, Okafor CI, Emehel A, Mbah AU, Onyia U et al. Pattern of blood pressure indices among the residents of a rural community in south east Nigeria, Int $\mathrm{J}$ Hypertens 2011, 2011: 621074.

20. Kadiri S, Walker O, Salako BL, Akinkugbe O. Blood pressure, hypertension and correlates in urbanized workers in Ibadan, Nigeria: a revisit. J Hum Hypertens 1999; 13:23-27.

21. Adienbo OM, Hart VO, Oyeyemi WA. High prevalence of obesity among indigenous residents of a Nigerian ethnic group: The Kalabaris in the Niger Delta region of southsouth Nigeria. Greener J Med Sci.2012; 2:152156.

22. Ejim EC, Okafor CI, Emehi A, Mbah AU, Onyia $\mathrm{U}$, Egwuonwu $\mathrm{T}$ et al. Prevalence of cardiovascular risk factors in the middle-aged and elderly population of a Nigerian population. J Trop Med 2011; 2011:308687. doi:10.,1155/ 2011/308687.

23. Okesina AB, Oparinde DP, Akindoyin KA, Erasmus RT. Prevalence of some risk factors of coronary heart disease in a rural Nigerian population. East Afr Med J. 1999; 76(4): 212-216.

24. Centers for Disease Control and Prevention National Diabetes Fact Sheet: General Information and National Estimates on Diabetes in the United States, 2011. Atlanta, Georgia, U.S. Department of Health and Human Services, Centers for Disease Control and Prevention 2011.

25. American Diabetes Association. Standards of Medical Care in Diabetes - 2012. Diabetes Care. 2012;35(3): 660 .

26. Apidechkul, T. Prevalence and factors associated with type 2 diabetes mellitus and hypertension among the hill tribe elderly populations in northern Thailand. BMC Public Health 18, 694 (2018). https://doi.org/ 10.1186/s12889-018-5607-2

27. Tsimihodimos V, Gonzalez-Villalpando C, Meigs JB, Ferrannini E. Hypertension and diabetes co-prediction and time trajectories. Hypertension 2018.71(3):422-428.

28. Sasai H, Sairenchi T, Iso H, Irie F, Otaka E, Tanaka K. Relationship between obesity and incident diabetes in middle aged and older Japanese adults: The Ibaraki Prefectural Health Study. Mayo Clin Proc 2010; 85(1):36- 40.

29. Shivananda N, Kheleel S, Shivang S, Vashista S, Rukaiya S, Safayah S et al. Investing the link between benign prostatic hypertrophy, BMI, and type 2 diabetes mellitus. Diabetes \& Metabolic Syndrome: Clinical Research Reviews. 2017; 11(Siup2): S627-30. 